\title{
A STUDY OF CLINICO-PATHOLOGICAL CONCORDANCE IN PATIENTS WITH HANSEN'S DISEASE ACROSS THE SPECTRUM
}

\author{
Lakshmy R ${ }^{1}$, K. Abdul Samad ${ }^{2}$, G. Nandakumar ${ }^{3}$, Joan Felicita Samson 4 \\ 1 Junior Resident, Department of Dermatology and Venereology, Government Medical College, Trivandrum, Kerala. \\ ${ }^{2}$ Additional Professor, Department of Dermatology and Venereology, Government Medical College, Trivandrum, Kerala. \\ ${ }^{3}$ Additional Professor, Department of Pathology, Government Medical College, Trivandrum, Kerala. \\ ${ }^{4}$ Professor, Department of Dermatology and Venereology, Dr. Somervell Memorial CSI Medical College, Karakonam, Trivandrum, \\ Kerala.
}

\section{ABSTRACT}

\section{BACKGROUND}

Leprosy is a disease showing wide variations in its clinical presentations and disparities between clinical and histopathological presentations.

The aim of this study was to assess the extent of correlation between clinical and histopathological diagnosis in cases diagnosed with leprosy.

\section{MATERIALS AND METHODS}

The primary objective was to study the concordance between clinical and histopathological presentations of Hansen's disease across the spectrum and to assess the rate of concordance between them. It was a descriptive study done in the Department of Dermatology and Venereology, Medical College, Thiruvananthapuram for a period of 11/2 years (From November 2012 to May 2014). All new (Untreated) cases of Hansen's disease who attended the department during the study period were included in the study.

\section{RESULTS}

A total of 45 patients were included in the study, but since one patient showed inconclusive histopathological features of leprosy he was eliminated and statistical analysis was done in 44 cases. In general, clinico-pathological concordance was observed in $63.6 \%$ of cases and discordance was observed in $36.4 \%$ of cases; $100 \%$ concordance was seen in indeterminate and tuberculoid cases and $100 \%$ discordance was observed in borderline lepromatous and histoid cases. Concordance rate was high in borderline tuberculoid (77.8\%) and discordance rate was high in lepromatous cases (57.1\%).

Limitation- The main limitation of this study was the small sample size, as many cases in this part of the country were treated at peripheral centres and there were no facilities for co-ordination with such centres for a more elaborate study.

\section{CONCLUSION}

The overall concordance was $63.6 \%$ and discordance was $36.4 \%$, which was similar to most of the previous studies; $100 \%$ concordance was observed in indeterminate and tuberculoid cases, whereas $100 \%$ discordance was observed in borderline lepromatous and histoid cases. Wide variations in clinico-pathological correlation was shown by borderline lepromatous cases, where the histopathological types showed features of borderline tuberculoid. Variations in clinico-pathological correlation was shown by borderline lepromatous cases, where the histopathological types showed features of borderline tuberculoid and mid borderline.

\section{KEYWORDS}

Leprosy, Clinico-Pathological Concordance.

HOW TO CITE THIS ARTICLE: Lakshmy R, Samad KA, Nandakumar G, et al. A study of clinico-pathological concordance in patients with Hansen's disease across the spectrum. J. Evolution Med. Dent. Sci. 2017;6(49):3742-3745, DOI: 10.14260/Jemds/2017/809

\section{BACKGROUND \\ Leprosy is a classic "spectral disease" being manifested in a} variety of clinical forms related to the type and strength of the immune response. ${ }^{1}$ The causative organism, Mycobacterium leprae (M. leprae) was discovered by Gerhard Henrik Armaeur Hansen, a Norwegian Leprologist in $1873 .^{2}$

Financial or Other, Competing Interest: None.

Submission 29-05-2017, Peer Review 11-06-2017,

Acceptance 13-06-2017, Published 19-06-2017.

Corresponding Author:

Dr. Abdul Samad K,

Additional Professor,

Department of Dermatology and Venereology,

Government Medical College,

Trivandrum-695011,

Kerala, India

E-mail: drsamad_1961@yahoo.co.in

DOI: $10.14260 /$ jemds $/ 2017 / 809$

(c) (i) $९$
Clinical presentation varies from a few to widespread lesions. Histopathology of skin lesions varies from compact granulomas to diffuse infiltration of dermis, which largely depends upon the immune status of the patient and may not be in agreement with the clinical diagnosis. However, clinical and histopathological disparities are seen due to varied clinical manifestations even in established leprosy and individual lesions may differ microbiologically and histologically. ${ }^{3}$

The present study was undertaken to assess the extent of correlation between clinical and histopathological diagnosis in cases diagnosed with leprosy.

\section{MATERIALS AND METHODS}

This study was conducted with the primary objective to study the concordance between clinical and histopathological presentations of Hansen's disease across the spectrum and to 
assess the rate of concordance between them. The secondary objective was to find out the possible determinants of discordance. A total of 45 cases were included in the study. It was a descriptive study done in the Department of Dermatology and Venereology, Medical College, Thiruvananthapuram for a period of 1-1/2 years (from November 2012 to May 2014). All new (untreated) cases of Hansen's disease who attended the department during the study period were included in the study. Clinical diagnosis was arrived at after independent examination by two different specialists and the histopathological features were analysed with the help of the expert dermatopathologist in the institution. Statistical analysis was done by applying appropriate statistical tools. The data were entered in Microsoft Excel and analysed using the computer software, Statistical Package for Social Science (SPSS).

\section{RESULTS}

Age

Maximum number of patients were in the age group $31-40$ years (18 patients, $40 \%$ ). The youngest patient was 12 years old and the eldest patient was 71 years old.

\section{Gender}

Out of the 45 patients, 33 were males $(73.3 \%)$ and 12 (26.7\%) were females.

\section{Duration of Symptoms}

Duration of the presenting complaints was more than 1 year in 20 patients $(44.4 \%)$. This was the largest group. In 13 patients $(28.9 \%)$ the duration was less than 6 months and in 12 patients $(26.7 \%)$ the duration was between 6 months and 1 year.

\begin{tabular}{|c|c|c|}
\hline Duration of Symptoms & Frequency & Percentage \\
\hline$<6$ months & 13 & 28.9 \\
\hline 6 months - 1 year & 12 & 26.7 \\
\hline$>$ 1 year & 20 & 44.4 \\
\hline Total & $\mathbf{4 5}$ & $\mathbf{1 0 0 . 0}$ \\
\hline \multicolumn{2}{|c|}{ Table 1. Duration of Symptoms } \\
\hline
\end{tabular}

\section{Clinical Diagnosis}

A clinical diagnosis of HD-Indeterminate was made in 3 patients (6.7\%), HD-TT in 1 patient (2.2\%), HD-BT in 28 patients $(62.2 \%)$, HD-BL in 5 patients $(11.1 \%)$, HD-LL in 7 patients $(15.6 \%)$ and Histoid leprosy in 1 patient $(2.2 \%)$. There was clinical evidence of nerve abscess in a patient who was clinically diagnosed as HD-BT (Table 2).

\begin{tabular}{|c|c|c|}
\hline Clinical Diagnosis & Frequency & Percentage \\
\hline HD-I & 3 & 6.7 \\
\hline TT & 1 & 2.2 \\
\hline BT & 28 & 62.2 \\
\hline BL & 5 & 11.1 \\
\hline LL & 7 & 15.6 \\
\hline Histoid & 1 & 2.2 \\
\hline Total & $\mathbf{4 5}$ & $\mathbf{1 0 0 . 0}$ \\
\hline \multicolumn{2}{|c|}{ Table 2. Clinical Diagnosis } \\
\hline
\end{tabular}

\section{Lepra Reactions}

There was clinical evidence of lepra reaction in 5 patients (11.1\%), in which type 1 lepra reaction was present in 3 patients $(6.7 \%)$ and type 2 lepra reaction in 1 patient $(2.2 \%)$. One patient $(2.2 \%)$ had clinical evidence of both type 1 and type 2 lepra reactions.

\section{Histopathological Diagnosis}

Histopathological diagnosis of Hansen's disease-Indeterminate was made in 5 patients $(11.4 \%)$, HD-TT in 5 patients $(11.4 \%), \mathrm{HD}-\mathrm{BT}$ in 24 patients $(54.5 \%)$, HD-BB in 3 patients (6.8\%), HD-BL in 3 patients (6.8\%) and HD-LL in 4 patients (9.1\%) (Table 3). One patient had an inconclusive biopsy report and hence he was excluded from further analysis of concordance.

\begin{tabular}{|c|c|c|}
\hline $\begin{array}{c}\text { Histopathological } \\
\text { Diagnosis (n=44) }\end{array}$ & Frequency & Percentage \\
\hline HD-I & 5 & 11.4 \\
\hline TT & 5 & 11.4 \\
\hline BT & 24 & 54.5 \\
\hline BB & 3 & 6.8 \\
\hline BL & 3 & 6.8 \\
\hline LL & 4 & 9.1 \\
\hline Total & 44 & 100.0 \\
\hline \multicolumn{2}{|c|}{ Table 3. Histopathological Diagnosis } \\
\hline
\end{tabular}

\section{Histopathological Evidence of Reaction}

There was evidence of type 1 lepra reaction (dermal oedema) in the dermis, which was seen in 2 patients (4.5\%) and type 2 lepra reaction in 1 patient $(2.3 \%)$.

\section{Correlation between Clinical and Histopathological Diagnosis}

As the biopsy of one patient showed inconclusive features only, this case was not taken for calculating concordance. So out of the other 44 cases, clinical and histopathological diagnoses were concordant in 28 cases (63.6\%) and discordant in 16 cases (36.4\%).

\section{Details of Correlation}

The details of clinicopathological correlation are as shown in Table 4.

\begin{tabular}{|c|c|c|c|c|c|c|c|c|}
\hline Clinical & No. of & \multicolumn{7}{|c|}{ Histopathological Diagnosis } \\
\cline { 5 - 10 } Diagnosis & Case & I & TT & BT & BB & BL & LL & Histoid \\
\hline HD-I & 3 & 3 & & & & & & \\
\hline HD-TT & 1 & & 1 & & & & & \\
\hline HD-BT & 27 & 2 & 4 & 21 & & & & \\
\hline HD-BB & 0 & & & & & & & \\
\hline HD-BL & 5 & & & 3 & 2 & & & \\
\hline HD-LL & 7 & & & & 1 & 3 & 3 & \\
\hline Histoid & 1 & & & & & & 1 & \\
\hline \multicolumn{8}{|c|}{ Table 4. Details of Correlation } \\
\hline
\end{tabular}

Based on this observation it was found that among the different types of Hansen's disease, the type which showed maximum discordance was HD-BL and Histoid leprosy followed by HD-LL. In HD-BT out of the 27 cases diagnosed clinically, 6 cases showed discordance. The details are summarised in the following table (Table 5). 


\begin{tabular}{|c|c|c|c|c|c|}
\hline $\begin{array}{c}\text { Clinical } \\
\text { Diagnosis }\end{array}$ & $\begin{array}{c}\text { Total } \\
\text { No. of Cases }\end{array}$ & $\begin{array}{c}\text { Histopathological } \\
\text { Diagnosis Consistent } \\
\text { with Clinical Diagnosis }\end{array}$ & $\begin{array}{c}\text { Percentage } \\
\text { of } \\
\text { Concordance }\end{array}$ & $\begin{array}{c}\text { Histopathological } \\
\text { Diagnosis not Consistent } \\
\text { with Clinical Diagnosis }\end{array}$ & $\begin{array}{c}\text { Percentage } \\
\text { of } \\
\text { Discordance }\end{array}$ \\
\hline HD-I & 3 & 3 & $100 \%$ & 0 & 0 \\
\hline HD-TT & 1 & 1 & $100 \%$ & 0 & 0 \\
\hline HD-BT & 27 & 21 & $77.8 \%$ & 6 & $22.2 \%$ \\
\hline HD-BB & 0 & - & - & 5 & $100 \%$ \\
\hline HD-BL & 5 & 0 & 0 & 4 & $57.1 \%$ \\
\hline HD-LL & 7 & 3 & $42.9 \%$ & 1 & $100 \%$ \\
\hline Histoid & 1 & 0 & 0 & $\mathbf{1 6}$ & $\mathbf{3 6 . 4 \%}$ \\
\hline Total & $\mathbf{4 4}$ & $\mathbf{2 8}$ & $\mathbf{6 3 . 6}$ & & \\
\hline \multicolumn{7}{r|}{} \\
\hline
\end{tabular}

Thus, it was observed that HD-I and HD-TT showed 100\% clinicopathological concordance and on the other hand, concordance rate in HD-LL was $42.9 \%$. There was $100 \%$ discordance in HD-BL and Histoid types.

\section{DISCUSSION}

It was observed that maximum number of patients were in the age group 31 - 40 years (40\%). In several other studies, the majority of patients were in the 21 - 30 years' age group, which is slightly lesser than seen in this study. ${ }^{4}$ There was a male preponderance $(73.3 \%)$ noted in the study, male-tofemale ratio being 2.8:1. This is in agreement with the rates observed in a study done by Bhushan et al in 2008, where the male-to-female ratio was $2.61: 1$ and also with the rates described in literature.5,6

The most common duration of the presenting complaints was more than 1 year, which was present in 20 patients (44.4\%). The shortest duration was 10 days and the longest duration was 10 years. In a study done by Reddy et al, it was noted that the duration of symptoms ranged from 1 month to 14 months. $^{7}$

Clinically, BT was the most common type of leprosy with 28 patients $(62.2 \%)$ and TT was the least diagnosed type with 1 patient (2.2\%). This is similar to the study done by Giridhar et al (BT 44\%). Mehta et al (BT 29\%) and the least were BB (6\%). ${ }^{8}$ These observations were dissimilar from that of the study done by Kalyani Mitra et al, where majority of the cases were TT. ${ }^{9}$

There was evidence of type 1 lepra reaction in 2 patients (4.5\%) and type 2 lepra reaction in 1 patient $(2.3 \%)$. Patnaiket et al found histologic findings of type 1 reaction in only $67.5 \%$ (27/40) patients with clinical features of reaction, but on the other hand found features of reaction in $20 \%$ $(10 / 50)$ of patients who had no clinical findings suggestive of a reaction. ${ }^{10}$

Overall, concordance was seen in 28 cases (63.6\%) and discordance in 16 cases (36.4\%). This finding was similar to a study done by Moorthy et al and Giridhar et al, where an overall clinico-pathological concordance of $62.63 \%$ and $60.23 \%$ were noted respectively. ${ }^{11,4}$ In another study by Ankur Kumar et al also, the overall correlation was $62.9 \%{ }^{12}$ In similar studies done by Mitra et al, Francisco VargasOcampo et al and Nitesh Mohan et al, the overall correlation was $53 \%, 42.9 \%$ and $56.4 \%$ respectively. $9,13,14$ Thus, the concordance rate is in agreement with that of many similar studies.

Maximum concordance was observed in HD-I and HD-TT, where there was $100 \%$ correlation. In the study by Ankur Kumar et al, 12 the highest correlation was in indeterminate leprosy (93.5\%). But in studies done by Mathur et al, 3
Shivaswamy et al ${ }^{15}$ and Giridhar et al, maximum correlation was observed in LL type which were $95.2 \%, 84.2 \%$ and 93.75\% respectively. Maximum discordance (100\%) was observed in BL and Histoid leprosy. Out of the 5 cases clinically diagnosed as BL none showed typical histopathological features of $\mathrm{BL}$, instead they showed features of BT in 3 cases and BB in 2 cases. This is similar to the study by Ankur Kumar et al, where maximum disagreement was in BL (78.7).12 Borderline tuberculoid showed a high concordance rate of $77.8 \%$ and lepromatous cases showed a high discordance rate of $57.1 \%$. From this study, it becomes obvious that the following factors may be attributable as causes for discordance-

1. The high immunological instability in borderline cases.

2. Biopsies taken from morphologically different lesions of various stages of progression of the disease in borderline cases.

3. The variation in the site of biopsy within the same lesion.

4. Differences in the age of the lesions biopsied.

\section{Limitations}

The main limitation of this study was the small sample size as many cases in this part of the country were treated at peripheral centres and there were no facilities for coordination with such centres for a more elaborate study.

\section{CONCLUSION}

This prospective descriptive study on leprosy to find out the concordance between clinical and histopathological diagnoses revealed that the overall concordance was $63.6 \%$ and discordance was $36.4 \%$, which was similar to most of the previous studies; $100 \%$ concordance was observed in indeterminate and tuberculoid cases, whereas 100\% discordance was observed in borderline lepromatous and histoid cases. Wide variations in clinico-pathological correlation was shown by borderline lepromatous cases where the histopathological types showed features of borderline tuberculoid and mid borderline. This points to the necessity of applying clinical judgement by the observer taking into account the relevant aspects in both clinical and histopathological features in arriving at the final conclusion.

\section{REFERENCES}

[1] World Health Organization. WHO expert committee on leprosy. Eighth report. WHO technical report series No: 968. Geneva: World Health Organization 2012:154. 
[2] Carpenter CM, Naylor-Foote AWC. The bacteriology of leprosy. In: Cochrane RG (edr). Leprosy in theory and practice. $1^{\text {st }}$ edn. Bristol: John Wright and sons Ltd 1959:p 7.

[3] Mathur MC, Ghimire RB, Shrestha P, et al. Clinicohistopathological correlation in leprosy. Kathmandu Univ Med J 2011;9(36):248-51.

[4] Giridhar M, Arora G, Lajpal K, et al. Clinicohistopathological concordance in leprosy - a clinical, histopathological and bacteriological study of 100 cases. Indian J Lepr 2012;84(3):217-25.

[5] Jopling WH, McDougall AC. Handbook of leprosy. Definition, epidemiology and world distribution. Chapter 1. $5^{\text {th }}$ edn. New Delhi: CBS publishers and Distributers 1996:1-9.

[6] Premanshu B, Sardana K, Koranne RV, et al. Diagnosing multibacillary leprosy: a comparative evaluation of diagnostic accuracy of slit-skin smear, bacterial index of granuloma and WHO operational classification. Indian J Dermatol Venereol Leprol 2008;74(4):322-6.

[7] Reddy RR, Singh G, Sacchidanand S, et al. A comparative evaluation of skin and nerve histopathology in single skin lesion leprosy. Indian J Dermatol Venereol Leprol 2005;71(6):401-5.

[8] Mehta B, Desai N, Khar S. Clinico-Pathological corelation in leprosy. Internet J Dermatol 2012;9(1).
[9] Mitra K, Biswas S, Saha B, et al. Correlation between clinical and histopathological criteria for the classification of leprosy. Indian J Dermatol 2001;46(3):135-7.

[10] Patnaik N, Agarwal S, Sharma S, et al. Evaluation of key histologic variables in skin biopsies of patients of borderline leprosy with type 1 lepra reaction. Indian J Dermatol Venereol Leprol 2014;80(5):402-8.

[11] Moorthy BN, Kumar P, Chatura KR, et al. Histopathological correlation of skin biopsies in leprosy. Indian J Dermatol Venereol Leprol 2001;67(6):299-301.

[12] Kumar A, Negi SR, Vaishnav K. A study of clinicohistopathological correlation of leprosy in a tertiary care hospital in western district of Rajasthan. J Res Med Den Sci 2014;2(3):43-8.

[13] Mohan N, Mishra N. Clinico histopathological correlation within the spectrum of hansen's disease: a multicentric study in North India. Int J Med Res Health Sci 2013;2(4):887-92.

[14] Vargas-Ocampo F. Analysis of 6000 skin biopsies of the national leprosy control program in Mexico. Int J Lepr 2004;72(4):427-36.

[15] Shivaswamy KN, Shyamprasad AL, Sumathy TK, et al. Clinico histopathological correlation in leprosy. Dermatology Online J 2014;18(9):2. 